\title{
IAMJ
}

INTERNATIONAL

AYURVEDIC

MEDICAL JOURNAL

\section{A CONTROLLED CLINICAL STUDY TO EVALUATE THE EFFICACY OF KARPASASTHYADI TAILA NASYAKARMA IN THE MANAGEMENT OF GREEVA ASTHIGATAVATA VIS- A-VIS CERVICAL SPONDYLOSIS}

\author{
Asha Rani K ${ }^{1}$, Umashankar. K. S ${ }^{2}$ \\ ${ }^{1}$ Assistant Professor, Department of Kayachikitsa, Sushrutha Ayurvedic Medical College and Hospital, \\ Prashanthi Kuteeram, Jigani Hobli, Anekal Taluk, Bengaluru-560106, Karnataka, India \\ ${ }^{2}$ Professor \& HOD, Department of Panchakarma, Government Ayurvedic Medical College and Hospital, New \\ Sayaaji Roa Road, Mysore -570001, Karnataka, India
}

Email: asharanikmys@gmail.com

https://doi.org/10.46607/iamj.0909012021

(Published online: January 2021)

Open Access

(C) International Ayurvedic Medical Journal, India 2021

Article Received: 28/12/2020 - Peer Reviewed: 30/12/2020 - Accepted for Publication: 02/01/2021

Check for updates

ABSTRACT

Asthigatavata is one among Shoola and Shosha Pradhana Vatavyadhi characterized by Asthishosha (Osteoporosis), Asthibheda (Cutting pain in bony joints), Asthishoola, Sandhishoola (Joint pain), Bedhaasthiparvanam (Splitting pain in bones and joints), Mamsabalakshaya (Loss of muscle strength), Aswapna (Insomnia) and Satata Ruk (Continuous pain). When Kupitha Vata Dosha enters in to the Asthi present in Greevapradesha causes series of changes producing symptoms and this clinical entity is named as Greeva Asthigatavata. Cervical Spondylosis is seen in the general population with the incidence rate of 83 per 100,000 and occurs mostly in fourth and fifth decades of life. More disability is seen over the age of 50years. Its prevalence is similar for both the sex, although the degree of severity is greater for males. Aim: To evaluate the therapeutic efficacy of Karpasasthyadi Taila Nasyakarma in the management of Greeva Asthigatavata vis-à-vis Cervical Spondylosis. Materials and Methods: It was a controlled clinical study with pre and posttest design. Total 100 subjects were incidentally selected and assigned into two groups viz., Group A (Control group) and Group B (Test group), with 50 subjects in each group. Subjects of Control Group were subjected with Greevabasti with Mahamasha Taila for 7 consecutive days and Astavarga Kashaya internally for 14 consecutive days from the first 
day of Greevabasti. Subjects of Test Group were subjected to Nasyakarma with Karpasasthyadi Taila for 7 consecutive days along with Greevabasti with Mahamasha Taila for 7 consecutive days and Astavarga Kashaya internally for 14 consecutive days from the first day of Nasyakarma. The study consisted of 3 assessments i.e on 0th day, 7th day and on 14th day. Result: In the study it was observed that Group B $(C C=0.529)$ showed clinically and statistically highly significant results with respect to reduction of symptoms than Group A (CC $=0.389)$ with high contingency coefficient value. Also, the overall assessment showed clinically and statistically highly significant result in both groups with $\mathrm{p}$ value 0.000. Conclusion: On comparing the overall effect of the study, trial group (Group B) showed better results than control group (Group A). Hence, Karpasasthyadi Taila has a better role in the management of Greeva Asthigatavata.

Keywords: Greeva Asthigatavata, Cervical Spondylosis, Karpasasthyadi Taila, Nasyakarma, Mahamasha Taila, Greevabasti, Astavarga Kashaya.

\section{INTRODUCTION}

Degenerative joint disorders are the major concern in the mankind causing pain in old age. Cervical Spondylosis is one such degenerative condition that is commonly encountered in old age. But because of the changed lifestyle, advancement in professional and social life, improper sitting posture, continuous work in one posture and over exertion in work place, jerking movements during travelling and sports, even most of the young and middle age people are victims of Cervical Spondylosis.

Asthigatavata is one among Shoola and Shosha Pradhana Vatavyadhi which is mentioned in the context of "Gatavata" in classical text". It is characterized by Asthishosha, Asthibheda, Asthishoola ${ }^{2}$ Sandhishoola, Bedhaasthiparvanam, Mamsabalakshaya, Aswapna, Satata Ruk ${ }^{3}$. When Kupitha (Aggravated) Vata Dosha enters into the Asthi (Vertebrae) present in Greeva Pradesha (Neck region) causes a series of changes producing symptoms and this clinical entity is named as Greeva Asthigatavata. All features mentioned earlier will be exhibited in the region of Greeva. Cervical Spondylosis is an agerelated degenerative disorder. Pathology generally starts at C5-6 \& C6-7 (More susceptible at C5-6) Vertebrae and gradually degenerates the annulus fibrosus and reduces inter-vertebral disc space and formation of osteophyte presenting with Neck pain, Neck stiffness, Radiculopathy, Headache, Restricted movement of Neck, Paraesthesia, Weakness, Sensory loss in upper limb and Vertigo ${ }^{4}$. Cervical Spondylosis is seen in the general population with the incidence rate of 83 per 100,000 . Population and prevalence of 3.3 cases per 1000 people and occurs mostly in fourth and fifth decades of life ${ }^{5}$. More disabilities are seen over the age of 50years. The prevalence of Cervical Spondylosis is similar for both the sex, although the degree of severity is greater for males ${ }^{6}$. There is no classical disease which can be equated precisely with Cervical Spondylosis but on the basis of core pathogenesis, this condition can be correlated to Greeva Asthigatavata. Western medical science provides both conservative and surgical treatment for Cervical Spondylosis. Subjects will be on medication/ treatment for a longer period of time because of its chronicity ${ }^{7}$. It targets only pain relief, using NSAID's, analgesics and muscle relaxants, which may have many side effects like gastric irritation. Even after such medical treatment, there is progressive cord dysfunction and persistent pain. Surgery is indicated when there is failure of conservative treatment for 10-12 weeks and when there is a progressive neurological deficit due to root or cord compressions $^{8}$. In the above situation, Ayurveda mentions a reliable therapy for Greeva Asthigatavata / Cervical Spondylosis which is an important area for research. The treatment modalities described in Ayurveda for Greeva Asthigatavata includes the Upakramas (Treatment modalities) mentioned in Vatavaydhi and specific modalities mentioned for Asthigatavata. Among which Nasyakarma as indicated in Vatajanya Urdhwajatrugta Vyadhis", with 
Karpasasthyadi Taila ${ }^{10}$ and Greevabasti, a Sthanika Snigdha Sweda with Mahamasha Taila ${ }^{11}$ does Dhatu Poshana (Tissue nourishment), Vedana Sthapana (Analgesic) and Asthi Poshana (Nourishment to bony joints). Astavarga Kashaya is a Vatahara Kashaya ${ }^{12}$ which reduces Asthi Sandhishoola (Pain in bony joints). From this perspective the current study was undertaken to evaluate the efficacy of Karpasasthyadi Taila Nasyakarma in Greeva Asthigatavata viz-a-viz Cervical Spondylosis.

Aim and Objective: To evaluate the therapeutic efficacy of Karpasasthyadi Taila Nasyakarma in the management of Greeva Asthigatavata vis-à-vis Cervical Spondylosis.

\section{Materials and Methods}

\section{Materials}

The Materials used in the study were:

1. Karpasasthyadi Taila

2. Astavarga Kashaya

3. Mahamasha Taila

Karpasasthyadi Taila, Mahamasha Taila, Astavarga Kashaya were specifically prepared as per the classics from NKCA Pharmacy Pvt Ltd., Krishna Raja Mohalla, Mysuru, a GMP certified unit, were procured for the purpose of study.

Methods: Source of data: Subjects were selected from the O.P.D. and I.P.D. of Government Ayurveda Medical College Hospital, Mysuru.

\section{Sample size and Sampling method}

A total of 110 subjects irrespective of gender, socioeconomic status and religion, having the signs and symptoms of Greeva Asthigatavata vis-a-vis Cervical Spondylosis fulfilling the inclusion criteria were registered for the study. The selected subject's detailed profile was prepared as per the detailed proforma designed for the same purpose, which incorporates relevant data like symptomatology, physical signs, laboratory investigation reports as well as assessment criteria after taking informed Consent of the subject. Incidental selection and Purposive sampling technique was employed. Subjects were assigned into two groups viz., Group A (Control group) and Group B (Trial group). Out of 110 subjects registered, Group A consisted of 56 subjects and Group B with 54 subjects.
There were 10 dropouts, 6 in Group A and 4 in Group $\mathrm{B}$ and the study was completed in 100 subjects with 50 subjects in each group.

\section{Inclusion Criteria}

- The subjects with the symptoms of Greeva Asthigatavata vis-à-vis Cervical Spondylosis including features of radiculopathy were included.

- Subjects irrespective of gender between the age group of 25 to 70 years were included.

- Subjects who were fit for Nasyakarma were included.

- Both the fresh and treated cases were included.

Exclusion criteria

- Subjects with major Systemic disorders that may interfere with the course of treatment were excluded.

- Subjects with congenital deformity, traumatic injuries, cervical stenosis \& myelopathy, ankylosing spondylosis, infections of bone and gross bony deformity and neoplastic conditions of spine were excluded.

- Pregnant and lactating women were excluded.

\section{Diagnostic criteria}

The Diagnosis was based on the following Lakshanas of Greeva Asthigatavata and clinical manifestation of Cervical Spondylosis viz., Greeva Asthi Sandhishoola (Neck pain and Radiation of pain), Mamsa Bala Kshaya (Weakness in upper extremities), Neck Stiffness, Restricted range of Neck movement, Paraesthesia, Vertigo, L hermit's sign, Spurling's sign, Shoulder abduction test, Plain X-Ray of Cervical Spine - AP and Lateral views and Kellgren- Lawrence Radiographic Grading Scale of Cervical Spondylosis.

Study Design: The present study was a controlled clinical study with pre and post test design.

Intervention: The interventions were as follows

\section{Group A - Control Group}

1. Greevabasti with Mahamasha Taila (approximately $250 \mathrm{ml}-300 \mathrm{ml}$ ) was carried out for 45 minutes per day, for 7 consecutive days.

2. Astavarga Kashaya in the dosage of $45 \mathrm{ml}$ in three equal divided doses, thrice daily after food was administered for 14 consecutive days from the first day of Greevabasti. 
Period of intervention- 14 days

\section{Group B - Test Group}

1. Nasyakarma with Karpasasthyadi Taila was carried out in early morning in empty stomach in a dosage of 6 drops to each nostril for 7 consecutive days along with Greevabasti with Mahamasha Taila (approximately $250 \mathrm{ml}-300 \mathrm{ml}$ ) for 45 minutes per day, for 7 consecutive days.

The subjects were instructed to follow the regimens during and after Nasyakarma.

2. Astavarga Kashaya in the dosage of $45 \mathrm{ml}$ in three equal divided doses, thrice daily after food was administered for 14 consecutive days from the first day of Nasyakarma.

Duration: Duration of the intervention 14 days

\section{Assessment}

Assessment parameters included the clinical grading of signs and symptoms of the disease Greeva Asthigatavata vis-a-vis Cervical Spondylosis viz neck pain, stiffness, radiation of pain, weakness in upper extremities, paraesthesia in upper extremities, vertigo, headache, sleep, tenderness over cervical region, movements of neck, sensory loss. In this Study, total three assessments of the subjects were done. The data were collected on 0 day (Pre-test/ before), on $7^{\text {th }}$ day (During) at evening hours and on $14^{\text {th }}$ day (Posttest/after) of completion of intervention.

\section{Overall Assessment}

The Overall assessment was graded with following manner:

Complete relief - Complete reduction in all the symptoms in subjects - Grade 0

Marked improvement- Reduction in all the signs and symptoms except any one symptom in subjects - Grade 1

Moderate improvement- Reduction in all the signs and symptoms except any two symptoms in subjects Grade 2

Mild improvement- Reduction in all the signs and symptoms except any three symptoms in subjects Grade 3

Insignificant improvement - No Reduction in any signs and symptoms in subjects - Grade 4
Statistical methods: The results were analyzed statistically by using Descriptive-independent statistics, Chi-square test, Student t test, ANOVA and Contingency co-efficient test analysis using Service product for statistical solution (SPSS) for windows software.

\section{Investigations}

X-ray Cervical Spine AP \& Lateral view was done for diagnosis as well as to exclude cervical fracture and indications for surgery. Blood routine - $\mathrm{Hb} \%, \mathrm{TC}, \mathrm{DC}$, ESR, RA, FBS, PPBS; Urine routine - Sugar, Albumin, Micro and other relevant investigations in appropriate cases were done to rule out systemic disorders.

\section{OBSERVATIONS}

The observations made in the present study were based on the clinical trial on 50 subjects in each Group. In the present study, maximum subjects belonged to the age group 41-60 years denoting that the highest number of data was between the fourth, fifth and sixth decade of age. This confirms the relation of advanced age with disease etiology. Prevalence of Cervical Spondylosis is more common in the fourth and fifth decade of life (is more prevalent in age groups 31 to 40 and 41 to 50 years. Maximum subjects belonged to heavy physical activity (49 subjects) and moderate physical activity (48 subjects). In the study, Occupation of Heavy physical activity involved coolly workers, mansion workers, farmers, Gymnastic people, Carpenters. Occupation of moderate physical activity involved Tailors, Housewives, Dancers, Bus \& Lorry drivers, two wheelers drivers. Occupation of sedentary occupation involved Teachers, Engineers, Bank employees and Housewives. This signifies that the disease Greeva Asthigatavata vis-a-vis Cervical Spondylosis is more prevalent in the occupation which involves improper ergonomics with continuous working in one place, writing bills, driving for long distances, who have excessive physical strain and activities that puts undue stress on the neck for prolonged periods, faulty sitting and working postures, which all corresponds to the etiology of Cervical Spondylosis. This may lead to the abuse of cervical spine and causes sustained heavy load on Cervical inter vertebral disc leading to tear in annulus fibrosis, 
manifesting as Cervical disc herniation. Although all 100 subjects had degenerative changes in the cervical spine radiographically, but the level of degeneration varied from one subject to another subject. In the present study, presence of 5 grades of Cervical Spondylosis denotes that patient may present with radio graphically insignificant Cervical Spondylosis or may present with osteophytes with or out significant joint space narrowing.

\section{RESULTS}

\section{Pre-test}

In Control Group among 50 subjects pain was severe in $22(44.0 \%)$, moderate pain in $17(34.0 \%)$, mild pain in $10(20.0 \%)$ and 1 subject had no pain. Stiffness was severe in 1 subject $(2.0 \%)$, moderate stiffness in 7 $(14.0 \%)$, mild stiffness in $2(4.0 \%)$ and 40 had no stiffness. Regarding radiation of pain $18(36.0 \%)$ belonged to grade R2, $17(34.0 \%)$ in grade R1, 7 $(14.0 \%)$ in grade R4, $5(10.0 \%)$ in grade R3 and 3 $(6.0 \%)$ in Grade R0. Regarding Weakness $3(6.0 \%)$ had weakness in both upper extremities, $7(14.0 \%)$ had weakness in anyone upper extremity, 40 (80.0\%) had no weakness. Paraesthesia was present in 30 subjects $(60.0 \%)$ and absent in 20(40.0\%). 7 subjects $(14.0 \%)$ had Vertigo on neck movements / occasionally and absent in 43(86.0\%). Regarding Headache 6 subjects $(12.0 \%)$ belonged to grade $\mathrm{H} 3,3(6.0 \%)$ in grade $\mathrm{H} 2,1$ $(2.0 \%)$ in grade $\mathrm{H} 1$ and $40(80.0 \%)$ in grade $\mathrm{H} 0.13$ (26.0\%) had moderately disturbed sleep (2-3 hours sleepless), 12 (24.0\%) had mildly disturbed sleep (1-2 hours sleepless), $12(24.0 \%)$ had slightly disturbed sleep (less than 1 hour sleepless) and 13 (26.0\%) had no sleeplessness. Regarding Tenderness over cervical spine region $7(14.0 \%)$ belonged to $3^{\text {rd }}$ grade, 27 $(54.0 \%)$ in $2^{\text {nd }}$ grade, $9(18.0 \%)$ in $1^{\text {st }}$ grade and 7 $(14.0 \%)$ in 0 grade. Regarding painful/ restricted movements of neck $14(28.0 \%)$ belonged to 6th grade, $6(12.0 \%)$ in 5 th grade, $7(14.0 \%)$ in 4 th grade, 12 $(24.0 \%)$ in 3rd grade, $8(16.0 \%)$ in 2 nd grade, $2(4.0 \%)$ in 1 st grade and $1(2.0 \%)$ in 0 grade . $2(4.0 \%)$ had reduced sensation and $48(96.0 \%)$ had normal sensation.
In Trial group $18(90.0 \%)$ reported with severe pain and $2(10.0 \%)$ with moderate pain. $5(10.0 \%)$ reported moderate stiffness, $6(12.0 \%)$ had mild stiffness and $39(78.0 \%)$ had no stiffness. Regarding radiation of pain 17 (34.0\%) belonged R2, 15 (30.0\%) in R1, 7 (14.0\%) in R4, $8(16.0 \%)$ in R3 and $3(6.0 \%)$ in R0. $2(4.0 \%)$ had weakness in both upper extremities, $16(32.0 \%)$ had weakness in anyone upper extremity, $32(64.0 \%)$ had no weakness. Paraesthesia was present in 34 subjects $(68.0 \%)$ and absent in $16(32.0 \%) .10$ subjects (20.0\%) had Vertigo on neck movements / occasionally and absent in 40 subjects $(80.0 \%)$. Regarding Headache $11(22.0 \%)$ belonged to grade $\mathrm{H} 3,7(14.0 \%)$ in grade $\mathrm{H} 2$ and $32(64.0 \%)$ in grade H0. $1(2.0 \%)$ had greatly disturbed sleep (3-5 hours sleepless), 13 (26.0\%) moderately disturbed sleep (2-3 hours sleepless), 17 $(34.0 \%)$ had mildly disturbed sleep (1-2 hours sleepless), 9 (18.0\%) had slightly disturbed sleep (less than 1 hour sleepless) and $10(20.0 \%)$ had no sleeplessness. Regarding Tenderness over cervical spine region 1 belonged to $4^{\text {th }}$ grade, $12(24.0 \%)$ in $3^{\text {rd }}$ grade, $27(54.0 \%)$ in $2^{\text {nd }}$ grade, $4(8.0 \%)$ in $1^{\text {st }}$ grade and $6(14.0 \%)$ in 0 grade. Regarding painful/ restricted movements of neck $19(38.0 \%)$ belonged to 6th grade, $5(10.0 \%)$ in 5th grade of, $8(16.0 \%)$ in to 4 th grade, 9 $(18.0 \%)$ in 3rd grade, $4(8.0 \%)$ in 2 nd grade, $4(8.0 \%)$ in 1 st grade and $1(2.0 \%)$ in 0 grade. $1(2.0 \%)$ had reduced sensation and $49(98.0 \%)$ had normal sensation.

\section{Mid test}

In Control Group among 50 subjects 31 subjects $(62.0 \%)$ had mild pain, $10(20.0 \%)$ had moderate pain and $9(18.0 \%)$ had no pain. $9(18.0 \%)$ had mild stiffness, and $41(82.0 \%)$ had no stiffness. Regarding radiation of pain 4 subjects $(8.0 \%)$ belonged to grade $\mathrm{R} 2,32(64.0 \%)$ in grade $\mathrm{R} 1,1(2.0 \%)$ in grade $\mathrm{R} 4$ and $13(26.0 \%)$ in grade R0. 1 subject $(2.0 \%)$ had weakness in both upper extremities, $5(10.0 \%)$ had weakness in anyone upper extremity and $44(88.0 \%)$ had no weakness. Paraesthesia was present in 21 subjects (42.0\%) and absent in 29 (58.0\%). Vertigo was present on neck movements / occasionally in $6(12.0 \%)$ and absent in 44 subjects $(88.0 \%) .1$ subject $(2.0 \%)$ belonged to grade $\mathrm{H} 2,8(16.0 \%)$ in grade $\mathrm{H} 1$ and 41 
(82.0\%) in grade H0. 2 subjects $(4.0 \%)$ had mildly disturbed sleep (1-2 hours sleepless), 26 (52.0\%) had slightly disturbed sleep (less than 1 hour sleepless) and $22(44.0 \%)$ had no sleeplessness. Regarding Tenderness over cervical spine region 3 subjects $(6.0 \%)$ belonged to $2^{\text {nd }}$ grade, $31(62.0 \%)$ in $1^{\text {st }}$ grade and $16(32.0 \%)$ in 0 grade. Regarding painful/ restricted movements of neck 1 subject $(2.0 \%)$ belonged to 4th grade, $9(18.0 \%)$ in 3rd grade, 19 $(38.0 \%)$ in 2 nd grade, $19(38.0 \%)$ in 1 st grade and 2 $(4.0 \%)$ in 0 grade. $2(4.0 \%)$ had reduced sensation and $48(96.0 \%)$ had normal sensation.

In Trial Group among 50 subjects $13(65.00 \%)$ reported with mild pain and $7(35.0 \%)$ with no pain. $10(20.0 \%)$ reported with mild stiffness and $40(80.0 \%)$ had no stiffness. Regarding radiation of pain 5 subjects (10.0\%) belonged to grade R2, 33(66.0\%) in grade R1, $1(2.0 \%)$ in grade R3 and $11(22.0 \%)$ in grade 0.10 subjects $(20.0 \%)$ had weakness in anyone upper extremity and $40(80.0 \%)$ had no weakness. Paraesthesia was present in 29 subjects $(58.0 \%)$ and absent in $21(42.0 \%)$. Vertigo was present on neck movements / occasionally in 6 subjects $(12.0 \%)$ and absent in 44 subjects (88.0\%). 1 subject $(2.0 \%)$ belonged to grade $\mathrm{H} 2,17(34.0 \%)$ in grade $\mathrm{H} 1$ and 32 $(64.0 \%)$ in grade H0. 4 subjects $(8.0 \%)$ had mildly disturbed sleep (1-2 hours sleepless), 32 (64.0\%) had slightly disturbed sleep (less than 1 hour sleepless) and 14 (28.0\%) had no sleeplessness. Regarding Tenderness over cervical spine region 6 (12.0\%) belonged to $2^{\text {nd }}$ grade, $36(72.0 \%)$ in $1^{\text {st }}$ grade and 8 $(16.0 \%)$ in 0 grade. Regarding painful/ restricted movements of neck 2 subjects $(4.0 \%)$ belonged to 4 th grade, $11(22.0 \%)$ in 3rd grade, $21(42.0 \%)$ in 2 nd grade, $14(28.0 \%)$ in 1 st grade and 2 subjects $(4.0 \%)$ in 0 grade. $1(2.0 \%)$ had reduced sensation and 49 $(98.0 \%)$ had normal sensation.

\section{Post test}

In Control Group among 50 subjects 7 subjects $(14.00 \%)$ had mild pain and $43(86.0 \%)$ had no pain. 3 (6.0\%) had mild stiffness and 47(94.0\%) had no stiffness. Regarding radiation of pain 11 subjects (22.0\%) belonged to grade R1, 1(2.0\%) in grade R3 and $38(76.0 \%)$ in grade $\mathrm{R} 0.3$ subjects $(6.0 \%)$ had weakness in anyone upper extremity and $47(94.0 \%)$ had no weakness. paraesthesia was present in 6 subjects $(12.0 \%)$ and absent in $44(88.0 \%)$. all 50 subjects $(100.0 \%)$ vertigo was absent. 1 subject (2.0\%) belonged to grade $\mathrm{H} 1$ and $49(98.0 \%)$ in grade $\mathrm{H} 0.7$ subjects $(14.0 \%)$ had slightly disturbed sleep (less than 1 hour sleepless) and $43(86.0 \%)$ had no sleeplessness. Regarding Tenderness over cervical spine region 5 $(10.0 \%)$ belonged to $1^{\text {st }}$ grade and $45(90.0 \%)$ in 0 grade. Regarding painful/ restricted movements of the neck $3(6.0 \%)$ belonged to 2 nd grade, $28(56.0 \%)$ in $1 \mathrm{st}$ grade and $19(38.0 \%)$ in 0 grade. $1(2.0 \%)$ had reduced sensation and $49(98.0 \%)$ had normal sensation. In Trial Group among 50 subjects, 1 subject (2.0\%) reported with mild pain and $49(98.0 \%)$ had no pain. all 50 subjects $(100.0 \%)$ had no stiffness. Regarding radiation of pain 7 subjects $(14.0 \%)$ belonged to grade R1 and $43(86.0 \%)$ in grade 0 . All 50 subjects (100.0\%) had no weakness. Paraesthesia was present in 4 subjects $(8.0 \%)$ and absent in $46(92.0 \%) .2$ subjects $(2.0 \%)$ had Vertigo on neck movements / occasionally and absent in 48 subjects $(96.0 \%) .1$ subject $(2.0 \%)$ in grade $\mathrm{H} 1$ and $49(98.0 \%)$ in grade H0. 9 subjects $(18.0 \%)$ had slightly disturbed sleep (less than 1 hour sleepless) and $41(82.0 \%)$ had no sleeplessness. Regarding Tenderness over cervical spine region $1(16.0 \%)$ belonged to $1^{\text {st }}$ grade and $49(84.0 \%)$ in 0 grade. Regarding painful/ restricted movements of neck $5(10.0 \%)$ belonged to 2nd grade, $19(38.0 \%)$ in 1st grade and $26(52.0 \%)$ in 0 grade. $1(2.0 \%)$ had reduced sensation and $49(98.0 \%)$ had normal sensation. Group A depicted highly significant $(\mathrm{p}<0.001))$ results in neck pain, neck stiffness, radiation of pain, paraesthesia in upper extremities, headache, sleeplessness, tenderness over cervical spine region, movements of neck and insignificant results in weakness in upper extremities, vertigo and sensory loss.

Group B depicted highly significant $(\mathrm{p}<0.001))$ results in neck pain, neck stiffness, radiation of pain, weakness in upper extremities, paraesthesia in upper extremities, vertigo, headache, sleeplessness, tenderness over cervical spine region, movements of neck and insignificant results in sensory loss. After the completion of the study, the result obtained regarding 
the overall assessment showed better results in Group $\mathrm{B}(\mathrm{CC}=0.529)$ than Group A $(\mathrm{CC}=0.389)$ with high contingency coefficient value. In Group A (Control group), the result obtained regarding the overall assessment showed complete relief in 11 subjects $(22.0 \%)$, marked improvement in $16(32.0 \%)$, Moderate improvement in $9(18.0 \%)$ and mild improvement in 14 (28.0\%). In Group B (Trial group), the result obtained regarding the overall assessment showed complete relief in 14 subjects $(28.0 \%)$, marked improvement in $22(44.0 \%)$ and Moderate improvement in $14(28.0 \%)$. The result obtained regarding the overall assessment also showed highly significant results in both groups with $\mathrm{p}$ value 0.000 .

\section{DISCUSSION}

The treatment modalities described in Ayurveda for Greeva Asthigatavata includes the Upakramas mentioned in Vatavaydhi and specific modalities mentioned for Asthigatavata. Nasyakarma as indicated in Vatajanya Urdhwajatrugta Vyadhis. Greevabasti acts as Sthanika Snigdha Sweda. Ingredients of Karpasasthyadi Taila have Madhura, Tikta, Kashaya Rasa (Kulattha, Tila Taila, Punarnava, Shigru, Kusta), Katu Rasa (Chavya, Pippalimoola, Satahwa, Nagara, Sarsapa), Snigdha Guru Guna (Karpasasthi, Balamoola, Masha, Tila Taila, Aja Ksheera), Ushna Veerya (Devadaru, Rasna, Kustha, Sarsapa, Nagara, Satahwa, Pippalimoola, Shigru), Madhura Vipaka and Vata Kapha hara property. All the ingredients are predominantly Vatahara. It has Asthi Poshaka, Vedana Sthapaka and Vata Kapha Pradhana Tridoshahara property which have essentially helped in Poshana of Greevasthi and in reduction of signs and symptoms. This might be the reason to get better results in Group B. Ingredients of Mahamasha Taila does Dhatu Poshana, Vedana Sthapana and Asthi Poshana. Astavarga Kashaya is a Vatahara Kashaya which reduces Asthi Sandhishoola.

\section{CONCLUSION}

On the basis of concepts, analysis and clinical observations made in this study, the following conclusions were drawn. Cervical disc disease is emerging as one of the most common diseases especially of the general population. It is commonly seen in society as a prominent problem. The prevalence of this disease has been expected to be increasing due to improper lifestyle, poor working, sleeping and sitting postures. It is an age-related degenerative disorder. Pathology generally starts at C5-6 \& C6-7 (More susceptible at C5-6) Vertebrae and gradually degenerates the annulus fibrous and reduces inter vertebral disc space and formation of osteophyte presenting with Neck pain, Neck stiffness, Radiation of pain, Headache, Restricted movements of Neck, Paraesthesia, Weakness, Sensory loss in upper limb and Vertigo. There is no classical disease which can be equated precisely with Cervical Spondylosis but on the basis of core pathogenesis, this condition can be correlated to Greeva Asthigatavata. Greeva Asthigatavata is a variety of Gatavata, a type of Vatavyadhi, characterized by cracking type of pain in the bones and joints, piercing pain in the joints, diminution of muscle-tissue and strength, insomnia and constant pain. Being a type of Vatavyadhi, general Vata provocating factors are accepted as Nidana. Vyana Vayu and Shleshaka Kapha are essential components to produce Greeva Asthigatavata. The Dushyas such as Asthi, Mamsa, Majja; Srotas such as Astivaha, Mamsavaha and Majjavaha plays an important role in the pathology of the disease Greeva Asthigatavata. Disintegration of Samprapti is Chikitsa but in disorder like Cervical Spondylosis age related changes are present, complete reversal is not possible. Aim of the management is to check neurological deterioration, symptomatic relief, prevent further progression and to develop a feeling of well-being. Karpasasthyadi Taila explained in Taila Prakarana of Sahasrayoga, is a formulation indicated in Sarva Vatarogas was used in the study for the management of Greeva Asthigatavata as it is a Vatavyadhi. Also the Rasa, Guna, Veerya, Vipaka, and Doshaghnata of individual ingredients and the formulation as a whole was analyzed and hypothesized that it is having Vedana Sthapaka, Asthi Poshaka, Vata Doshahara property which is mainly 
required in the Samprapti Vighatana of the disease Greeva Asthigatavata. So, this formulation was selected as a trial in the present study, Greevabasti and Astavarga Kashaya (oral administration) was taken as a control. This is a controlled clinical study, conducted on 100 subjects with 50 subjects in each group. In the study it was observed that trial Group (Group B) showed clinically and statistically highly significant results; reduction of the Neck pain, Radiation of pain, Paraesthesia in upper extremities, Vertigo, Headache, Sleeplessness, Tenderness over Cervical region, Weakness in upper extremities, Headache and improvement in neck movements showed highly significant result with $\mathrm{p}$ value 0.000 ; showed highly significant result in reduction of Neck stiffness with $\mathrm{p}$ value 0.002 ; showed highly significant result in reduction of Vertigo with $p$ value 0.048 and showed no significant result in reduction of sensory loss with $\mathrm{p}$ value 0.813 . Control group (Group A) showed clinically and statistically highly significant result in reduction of the Neck pain, Radiation of pain, Paraesthesia, Headache, Sleeplessness, Tenderness over Cervical region, improvement in neck movements with $\mathrm{p}$ value 0.000 ; showed significant result in reduction of Neck stiffness ( $p$ value 0.002 ), Weakness ( $p$ value 0.226 ); showed no significant result in reduction of Vertigo $(\mathrm{p}$ value 0.087 ) and Sensory loss ( $p$ value 0.141). On comparing the overall effect of the study, trial group (Group B) showed better results than control group (Group A). Hence, Karpasasthyadi Taila has a better role in the management of Greeva Asthigatavata.

\section{REFERENCES}

1. Agnivesha, Charaka Samhita with Ayurveda deepika commentary by Chakrapani datta, (Ed) Vaidya Jadavaji trikamji Acharya, Chaukhamba Sanskrit Sansthan, Varanasi, Fourth edition, Chikitsa sthana 28/24-37, P.No- 617.

2. Sushruta, Sushruta Samhita with Nibandha Sangraha and Nyayachandrika commentary edited by Vaidya
Yadavji Trikamji Acharya and rest by Kavyatirtha, from $1^{\text {st }}$ chapter, Chaukambha Orientalia,Varanasi, $8^{\text {th }}$ Edition, 2005, Nidana sthana, 1/28 of, P.No-298.

3. Agnivesha, Charaka Samhitha, Ayurveda Dipika commentary by Chakrapanidatta, (Ed)Vaidya Jadavji Trikamji Acharya, Chaukamba Sanskrit Sansthan, Varanasi, Fourth edition, Chikitsa Sthana 28/33, P.No617.

4. Nicolas A. Boon, Nicki R Colledge and Brian R. walker, Davidson's principle and Practice of medicine, Churchill Livingstone Elsevier publication, 20th edition, reprint: 2006; Part-2, 26th chapter, Neurological Disease, P.No- 1241.

5. Ravishankar reddy, Arun maiya.G, Sharath kumar roa, proprioceptive Reposition errors in subjects with Cervical Spondylosis, International Journal of Health Sciences and Research, Vol-1, issue 2, 2011.

6. www.physio-pedia.com

7. David.G.Borenstein, Sam.W.Wiesel, Scott.D.Boden, Comprehensive Diagnosis and Management, Section 3 - Disease associated with Spinal pain, Chapter 10 Mechanical disorders of the spine, Jayapee brothers medical publication, New Delhi, $3^{\text {rd }}$ edition, P.No266.

8. Nicolas A. Boon, Nicki R Colledge and Brian R. walker, Davidson's principle and Practice of medicine, Churchill Livingstone Elsevier publication, 20th edition, reprint:2006; Part-2, 26th chapter, Neurological Disease, P.No- 1241.

9. Agnivesha, Charaka Samhita, Sri Chakrapanidatta virachita, edited by Vd.Jadavji Trikamaji Acharya, Chaukhamba Sanskrit Sansthan Varanasi, $5^{\text {th }}$ edition 2001, Siddhi Sthana, 2/22, P.No-690.

10. Anonymous, Sahasrayoga (Sanskrit Hindi Translation) translated by Dr.D.V. Pandit Rao, edited by Vaidya Mahendra Pal Simha Arya, New Delhi, Vanghamaya Evam Siddha Anusandhana Parishadh, 30th Nov 1990, Taila prakarana, No-15, P.No- 118.

11. Bhishagratna PT. Brahmashankara Mishra edited Chakradattsa of Sri Chakrapanidatta with the Bhavarthasandipini Hindi commentary, Vatavyadhichikitsa 22/192-200, Pub: Chowkhamba SanskritSansthana, 5th edition 107 series, P. No-202.

12. Anonymous, Sahasrayoga (Sanskrit Hindi Translation) translated by Dr.D.V. Pandit Rao, edited by Vaidya Mahendra Pal Simha Arya, New Delhi, Vanghamaya Evam Siddha Anusandhana Parishadh, 30th Nov 1990, Kashaya prakarana, P.No- 45. 
Table 1: Showing result on overall assessment

\begin{tabular}{|c|c|c|c|c|c|}
\hline & & & \multicolumn{2}{|c|}{ Groups } & \multirow[t]{2}{*}{ Total } \\
\hline & & & Control group & Trial Group & \\
\hline \multirow[t]{10}{*}{ Overall Assessment } & Complete relief & Count & 11 & 14 & 25 \\
\hline & & $\%$ of group & $22.0 \%$ & $28.0 \%$ & $2.50 \%$ \\
\hline & Marked improvement & $\%$ of group & 16 & 22 & 38 \\
\hline & & & $32.0 \%$ & $44.0 \%$ & $38.0 \%$ \\
\hline & Moderate improvement & count & 9 & 14 & 23 \\
\hline & & $\%$ of group & $18.0 \%$ & $28.0 \%$ & $23.0 \%$ \\
\hline & Mild improvement & count & 14 & 0 & 14 \\
\hline & & $\%$ of group & $28.0 \%$ & $0.0 \%$ & $14.0 \%$ \\
\hline & Insignificant improvement & count & 0 & 0 & 0 \\
\hline & & $\%$ of group & $0.0 \%$ & $0.0 \%$ & $0.0 \%$ \\
\hline \multirow{2}{*}{\multicolumn{2}{|c|}{ Total }} & count & 50 & 50 & 100 \\
\hline & & $\%$ of group & $100.0 \%$ & $100.0 \%$ & $100.0 \%$ \\
\hline
\end{tabular}

Table 2: Contingency coefficient value of Group A and Group B

\begin{tabular}{|l|l|l|}
\hline SYMPTOMS & GROUP A Contingency coefficient value & GROUP B Contingency coefficient value \\
\hline Neck Pain & 0.651 & 0.705 \\
\hline Neck Stiffness & 0.264 & 0.234 \\
\hline Radiation of pain to upper limb & 0.540 & 0.567 \\
\hline Weakness of upper limb & 0.137 & 0.277 \\
\hline Paraesthesia of upper limb & 0.389 & 0.489 \\
\hline Vertigo & 0.180 & 0.201 \\
\hline Headache & 0.297 & 0.464 \\
\hline Sleeplessness & 0.492 & 0.530 \\
\hline Tenderness & 0.638 & 0.694 \\
\hline $\begin{array}{l}\text { Neck movements } \\
\text { (painful/ restricted) }\end{array}$ & 0.649 & 0.653 \\
\hline Sensory loss of upper limb & 0.053 & 0.000
\end{tabular}

\section{Symptoms Scorings:}

\section{Neck Pain:}

N0 - No Pain

N1 - Mild Pain occasional/ intermittent

Relieved on its own/rest

N2 - Moderate Pain, frequent pain,

Relieved after taking analgesics

N3 - Severe Pain, not tolerable, not relieved fully

Even after taking analgesics

Stiffness:

S0 - No Stiffness

S1 - Mild Stiffness

S2 - Moderate Stiffness

S3 - Severe Stiffness

Radiation of Pain:
$\mathrm{R} 0$ - No radiation

R1 - Radiation of pain from neck to one arm, occasionaly

R2 - Radiation of pain from neck to arm, continuously R3 - Radiation of pain from neck to both arm, occasionaly

R4 - Radiation of pain from neck to both arm, continuously

\section{Weakness:}

W0- No weakness

W1 - Weakness in anyone upper extremity

W2 - Weakness in both upper extremities

Parasthesia:

PA0 - Absent

PA1 - Present 


\section{Vertigo:}

V0 - Absent

V1 - Present on neck movements / occasionally present V2 - Present constantly

\section{Headache:}

H0 - I have no headaches at all

H1 - I have slight headaches which come infrequently H2 - I have moderate headaches which come infrequently

H3 - I have moderate headaches which come frequently

H4 - I have severe headaches which come frequently

H5 - I have headaches almost all the time

\section{Sleeping:}

SL0 - I have no trouble sleeping

SL1 - My sleep is slightly disturbed (less than 1 hour sleepless)

SL2 - My sleep is mildly disturbed (1-2 hours sleepless)

SL3 - My sleep is moderately disturbed (2-3 hours sleepless)

SL4 - My sleep is greatly disturbed (3-5 hours sleepless)

SL5 - My sleep is completely disturbed (5-7 hours sleepless)

\section{Tenderness over Cervical region:}

T0 - No tenderness

$\mathrm{T} 1$ - Patient complains of tenderness

T2 - Patient complains of tenderness and winces
T3 - Patient winces and withdraws the affected part

T4 - Patient will not allow palpation of affected part

Movements of Neck- Painful or Restricted: (Flexion, Extension, Right Lateral Flexion, Left Lateral Flexion, Right Lateral Rotation, Left Lateral Rotation)

M0- All the 6 movements are painless or not restricted

M1 - Any 1 movement is painful or restricted

M2 - Any 2 movements are painful or restricted

M3 - Any 3 movements are painful or restricted

M4 - Any 4 movements are painful or restricted

M5 - Any 5 movements are painful or restricted

M6 - Any 6 movements are painful or restricted

Sensory Loss:

SL0 - Normal Sensation

SL1 - Reduced Sensation

SL2 - No Sensation

\section{Source of Support: Nil}

\section{Conflict of Interest: None Declared}

How to cite this URL: Asha Rani K \& Umashankar. K. S: A Controlled Clinical Study To Evaluate The Efficacy Of Karpasasthyadi Taila Nasyakarma In The Manage-ment Of Greeva Asthigatavata Vis- A-Vis Cervical Spondylosis. International Ayurvedic Medical Journal \{online\} 2021 \{cited January, 2021\} Available from: HYPERLINK "http://www.iamj.in/posts/images/upload/_.pdf" http://www.iamj.in/posts/images/upload/63 72.pdf 